\title{
Glosa do wyroku Wojewódzkiego Sądu Administracyjnego w Poznaniu z dnia 2 kwietnia 2014 r. I SA/Po 442/13
}

1.

Glosowany wyrok WSA dotyczy skargi organizacji pożytku publicznego $\mathrm{X}$ na rozstrzygnięcie Samorządowego Kolegium Odwoławczego w zakresie zobowiązania do zwrotu części dotacji udzielonej przez jednostkę samorządu terytorialnego na realizację zadania publicznego. Kwestią problematyczną w omawianej sprawie jest relacja przepisów ustawy z dnia 27 sierpnia $2009 \mathrm{r}$. o finansach publicznych ${ }^{1} \mathrm{z}$ postanowieniami ustawy z dnia 24 kwietnia 2003 r. o działalności pożytku publicznego i o wolontariacie $^{2}$ dotyczącymi zasad udzielania dotacji przez jednostki samorządu terytorialnego oraz interpretacja pojęcia „wykorzystanie dotacji”, czyli co należy rozumieć przez wykorzystanie dotacji: czy zrealizowanie celu, na który dotacja została udzielona, czy zapłatę za zrealizowanie zadania?

\footnotetext{
Tekst jedn. Dz.U. z 2013 r., poz. 1536 ze zm. (dalej: u.f.p.).

Tekst jedn. Dz.U z 2010 r., Nr 234, poz. 1536 ze zm. (dalej: u.d.p.p.w.).
} 


\section{2.}

Burmistrz Miasta i Gminy Y (zleceniodawca) zarządzeniem z kwietnia 2011 r. ogłosił otwarty konkurs ofert na powierzenie zadania publicznego polegającego na zorganizowaniu wypoczynku letniego dzieci i młodzieży z Gminy Y. W wyniku otwartego konkursu ofert wybrano ofertę organizacji pożytku publicznego X (zleceniobiorca). W maju 2011 r. została zawarta umowa na wykonanie tegoż zadania, w której termin realizacji zadania określono na okres od czerwca 2011 r. do sierpnia 2011 r. W związku z umową organizacja X otrzymała w czerwcu 2011 r. dotację z budżetu gminy $\mathrm{Y}$ na realizację zadania. Organizacja $\mathrm{X}$ zobowiązana była do złożenia sprawozdania $\mathrm{z}$ wykonania zadania w terminie $30 \mathrm{dni}$ od dnia zakończenia realizacji tego zadania. Przedmiotowe sprawozdanie nie wpłynęło w wyznaczonym terminie, dlatego w październiku 2011 r. Burmistrz pisemnie wezwał zleceniobiorcę do złożenia go $\mathrm{w}$ urzędzie. W kilka dni później do urzędu wpłynęło sprawozdanie, które jednak zawierało szereg uchybień natury formalnej. W konsekwencji w grudniu 2011 r. w organizacji X odbyła się kontrola zleceniodawcy w zakresie prawidłowości wykorzystania środków w ramach przekazanej dotacji. W wyniku kontroli stwierdzono wydatkowanie części przekazanych środków po terminie realizacji zadania oraz po terminie złożenia sprawozdania. Wobec powyższego zleceniodawca decyzją z lutego 2012 r. odstąpił od umowy i zażądał zwrotu całej dotacji wraz z odsetkami.

SKO decyzją z maja 2012 r. po rozpatrzeniu odwołania X uchyliło zaskarżoną decyzję w całości i przekazało sprawę do ponownego rozpatrzenia. Burmistrz po ponownym rozpatrzeniu sprawy decyzją z września 2012 r. zobowiązał X do zwrotu do budżetu Gminy kwoty dotacji wraz z odsetkami w wysokości określonej jak dla zaległości podatkowych, liczonych od dnia przekazania dotacji.

SKO po rozpoznaniu odwołania wydało w styczniu 2013 r. decyzję, mocą której uchyliło zaskarżoną decyzję w całości i jednocześnie orzekło, że X jest zobowiązane do zwrotu tej części dotacji, która została niewykorzystania w określonym w umowie terminie realizacji zadania wraz z odsetkami liczonymi jak od zaległości podatkowych od września 2011 r. do dnia zwrotu dotacji. 


\section{3.}

Stanowisko organu odwoławczego uznał za słuszne Wojewódzki Sąd Administracyjny w Poznaniu, który wskazał, że w sprawie mamy do czynienia z niewykorzystaniem dotacji w terminie, co wynika z przepisów normatywnych i z umowy zawartej w maju 2011 r. pomiędzy zleceniodawcą a zleceniobiorcą. Zgodnie z tą umową zleceniobiorca zobowiązany był wykorzystać środki finansowe z dotacji nie później niż do dnia zakończenia realizacji zadania. Sąd wskazał, że kwotę dotacji niewykorzystanej w terminie zleceniobiorca był zobowiązany zwrócić w terminie 15 dni od dnia zakończenia realizacji zadania. Podstawą zwrotu dotacji jest, zdaniem sądu, art. 251 u.f.p., określający zasady zwrotu dotacji udzielonych z budżetu jednostki samorządu terytorialnego w sytuacji ich niewykorzystania w określonym terminie. Zgodnie z art. 251 ust. 1 i ust. 3 u.f.p. dotacje udzielone z budżetu jednostki samorządu terytorialnego w części niewykorzystanej do końca roku budżetowego podlegają zwrotowi do budżetu tej jednostki w terminie do dnia 31 stycznia następnego roku (ust. 1). W przypadku, gdy termin wykorzystania dotacji, o których mowa w ust. 1, jest krótszy niż rok budżetowy, niewykorzystana część dotacji podlega zwrotowi w terminie 15 dni po upływie terminu wykorzystania dotacji.

Sąd nie podzielił poglądu organizacji pożytku publicznego X wrażającego się tym, że o wykorzystaniu dotacji nie decyduje data zapłaty ani data złożenia komukolwiek rachunku lub faktury. Zleceniobiorca argumentował, że przyznanie mu dotacji nastąpiło na podstawie przepisów odrębnych - tj. ustawy o działalności pożytku publicznego i wolontariacie - i że w odniesieniu do wykorzystania dotacji znajduje zastosowanie druga część art. 251 zawarta w ust. nr 4 u.f.p., stanowiąca, iż wykorzystanie dotacji następuje przez realizację celów wskazanych w przepisach odrębnych. Organizacja X podnosiła, że przepisy zawarte w ustawie o działalności pożytku publicznego i wolontariacie są odrębne od przepisów zawartych w ustawie o finansach publicznych i określają cele, dla osiągnięcia których dotacje są przyznawane, więc w konsekwencji „wykorzystanie dotacji” następuje poprzez realizację celów, a te w opinii organizacji X zostały osiągnięte. 


\section{4.}

Problematyka zwrotu dotacji była już przedmiotem rozważań sądów administracyjnych. W tej kwestii na gruncie przepisu art. 144 ust. 4 poprzedniej ustawy o finansach publicznych ${ }^{3}$ o jednakowej treści jak przepis art. 251 ust. 4 obecnej u.f.p. wypowiedział się Naczelny Sąd Administracyjny w wyroku z 15 lutego 2012 r. ${ }^{4}$ Sąd wskazał, że w obowiązującej wcześniej ustawie o finansach publicznych uregulowano dwie sytuacje związane z udzieleniem dotacji. Pierwsza odnosi się do dotacji uregulowanych w ustawie o finansach publicznych, druga zaś do tych, których udzielenie i rozliczenie normują przepisy odrębne. W art. 144 ust. 4 (art. 251 ust. 4) jako sposób wykorzystania dotacji wskazano zapłatę, jednakże użycie określenia „w szczególności” oznacza, że ten sposób zrealizowania dotacji nie jest jedynym możliwym. Zdaniem sądu brak jest podstaw do wykładni pojęcia „wykorzystanie dotacji” udzielonej na zrealizowanie zadania zawartego w art. 144 ust. 4 rozumianego w ten sposób, że wykorzystanie dotacji następuje wyłącznie przez zapłatę.

Z kolei w wyroku z dnia 28 listopada 2012 r. WSA w Krakowie ${ }^{5}$, orzekając w przedmiocie zwrotu dotacji, wskazał, że wykorzystanie dotacji udzielonej w trybie przepisów u.d.p.p.w. jest równoznaczne z wydatkowaniem przydzielonej kwoty poprzez zapłatę za zrealizowanie zadania. Zapłata powinna przy tym nastąpić w terminie do dnia zakończenia realizacji zadania. Kwota niewydatkowana w tym terminie musi zostać uznana za dotację niewykorzystaną, podlegającą zwrotowi.

5.

Jaka jest zatem relacja przepisów ustawy o działalności pożytku publicznego i o wolontariacie z postanowieniami ustawy o finansach publicznych w zakresie zasad udzielania dotacji przez jednostki samorządu terytorialnego?

\footnotetext{
Ustawa o finansach publicznych z dnia 30 czerwca 2005 r. (Dz.U. Nr 249, poz. 2104 ze zm.). Wyrok NSA z dnia 15 lutego 2012 r., SA II GSK 1509/10, Centralna Baza Orzeczeń Sądów Administracyjnych (CBOSA).

5 Wyrok WSA w Krakowie z dnia 28 listopada 2012 r., I SA/Kr 1459/12, CBOSA.
} 
Ustawa o działalności pożytku publicznego i wolontariacie usankcjonowała zasady współpracy pomiędzy organami jednostek samorządu terytorialnego a podmiotami prowadzącymi działalność pożytku publicznego ${ }^{6}$. Przedmiotowa ustawa określiła: zakres podmiotów uprawnionych do korzystania z dotacji (art. 3), zakres przedmiotowy dotacji (art. 4), zasady i procedurę przyznawania dotacji (art. 11-15), obowiązek kształtowania wzajemnych relacji w drodze umowy (art. 16 ust.1), zasady kontroli i sprawozdawczości (art. 17-18).

Ustawę tę charakteryzuje silne powiązanie z u.f.p. W art. 2 ust. 1 i 2 ustawodawca, definiując pojęcie dotacji i środków publicznych, odsyła do definicji zawartych w u.f.p. Podobnie jest też w przypadku określenia definicji jednostki sektora finansów publicznych (art. 3 ust. 2 pkt 1). Szczególne znaczenie w kontekście prowadzonych rozważań ma art. 5 ust. 2 pkt 1 oraz art. 5 ust. 4 stanowiące o zlecaniu organizacjom pozarządowym realizacji zadań publicznych. Wskazano w nich, że zlecanie realizacji zadań publicznych organizacjom pozarządowym odbywa się na zasadach określonych w u.f.p. jako zadań zleconych w rozumieniu art. 127 ust. 1 pkt 1 lit. e, art. 151 ust. 1 oraz art. 221. Z kolei w art. 16. ust. 1 wskazano na to, że organizacje pozarządowe lub podmioty wymienione w art. 3 ust. 3, przyjmując zlecenie realizacji zadania publicznego w trybie określonym w art. 11 ust. 2, zobowiązują się do wykonania zadania publicznego w zakresie i na zasadach określonych w umowie, odpowiednio o wsparcie realizacji zadania publicznego lub o powierzenie realizacji zadania publicznego, sporządzonej z uwzględnieniem art. 151 ust. 2 i art. 221 ust. 3 ustawy finansach publicznych, a organ administracji publicznej zobowiązuje się do przekazania na realizację zadania dotacji.

Art. 151 ust. 2 i art. 221 ust. 3 u.f.p. określają elementy jakie, musi zawierać umowa o powierzenie realizacji zadania publicznego. Są to: 1) szczegółowy opis zadania, w tym cel na jaki dotacja została przyznana i termin jego wykonania; 2) wysokość dotacji udzielanej podmiotowi

$6 \quad$ Zob. Szerzej: R. Musiałkiewicz, Problemy prawne udzielania dotacji na cele publiczne organizacjom pozarzqdowym przez jednostki samorzq̨y terytorialnego [w:] A. Borodo (red.), Zagadnienia prawne finansów i gospodarki samorzq̨du terytorialnego, Toruń 2008, s. 259-275. 
wykonującemu zadanie i tryb płatności; 3) termin wykorzystania dotacji; 4) tryb kontroli wykonywania zadania; 5) termin i sposób rozliczenia udzielonej dotacji; 6) termin zwrotu niewykorzystanej części dotacji.

Podkreślić należy również zasadę z art. 34 ust. 1 u.d.p.p.w. stanowiącą o tym, iż w zakresie nieuregulowanym w u.d.p.p.w. do nadzoru i kontroli wydatkowania środków publicznych stosuje się odpowiednio przepisy o finansach publicznych.

\section{6.}

Wobec powyższego, za słuszne należy uznać stanowisko WSA w Poznaniu w przedmiotowej sprawie. W świetle stanu de lege lata nie można za przepisy odrębne w rozumieniu art. 251 ust 4 u.f.p. uznać przepisów u.d.p.p.w. Dodatkowo, na co zwrócił uwagę sąd, u.d.p.p.w. nie określa celów, dla osiągnięcia których dotacja została przyznana.

Skonkretyzowanie celu następuje dopiero w umowie zawartej pomiędzy organizacją pożytku publicznego a jednostką samorządu terytorialnego - umowa taka powinna zawierać m.in. szczegółowy opis zadania, w tym cel, na jaki dotacja została przyznana. Zgodnie z procedurą udzielania dotacji zawartą w u.d.p.p.w. określanie celów realizacji zadania publicznego leży po stronie zleceniobiorcy. Zleceniobiorca formułuje zakładane cele realizacji zadania we wniosku o dofinansowanie, którego wzorzec został określony w sposób normatywny - rozporządzeniem Ministra Pracy i Polityki Społecznej z dnia 15 grudnia 2010 r. ${ }^{7}$ W części III formularza wniosku znajduje się punkt „zakładane cele realizacji zadania oraz sposób ich realizacji”, w którym podmioty ubiegające się o powierzenie bądź wsparcie realizacji zadania publicznego samodzielnie formułują treść stanowiącą o celu zadania. Akceptacja wniosku o dofinansowanie organizacji pozarządowej przez jednostkę zlecającą oznacza, że zawarte w nim postanowienia mają moc prawną, wniosek jest bowiem załącznikiem do umowy o dofinansowanie.

\footnotetext{
7 Rozporządzenie Ministra Pracy i Polityki Społecznej z dnia 15 grudnia 2010 r. w sprawie wzoru oferty i ramowego wzoru umowy dotyczących realizacji zadania publicznego oraz wzoru sprawozdania z wykonania tego zadania (Dz.U. z 2011 r., Nr 6 poz. 25).
} 
Sposób udzielenia i rozliczenia dotacji z budżetów jednostek samorządu terytorialnego dla organizacji pozarządowych zlecanych w trybie u.d.p.p.w. określają więc przepisy u.f.p., brak jest bowiem podstaw do przyjęcia, że wykorzystanie dotacji następuje poprzez zrealizowanie celu wskazanego w przepisach odrębnych. Cel nie jest formułowany w sposób normatywny, jego określenie zależy od swobodnego uznania zleceniobiorcy. Niewątpliwie u.d.p.p.w. stanowiła podstawę do zawarcia umowy z organizacją X. Jednakże z tej okoliczności nie można wywodzić, że przepisy tej ustawy są odrębnymi przepisami stanowiącymi o sposobie udzielenia i rozliczenia dotacji, o których mowa w art. 251 ust. 4 u.f.p.

\section{7.}

Przepisami odrębnymi w rozumieniu art. 251 ust 4 u.f.p., jak wskazano w uzasadnieniu do wyroku, są art. 80 ust. 4 oraz art. 90 ust. 4 ustawy z dnia 7 września 1991 r. o systemie oświaty ${ }^{8}$. Przepisy te odrębnie regulują tryb udzielania i rozliczania dotacji oraz tryb i zakres kontroli prawidłowości ich wykorzystywania oraz stanowią podstawę do transferów finansowych przekazywanych przez jednostkę samorządu terytorialnego na rzecz szkoły, przedszkola lub placówki oświatowej.

Można się zastanawiać, czy transfery te noszą cechy właściwe dla „dotacji podmiotowej”. Gdyby je uznać za takie, wówczas dotacja podmiotowa zgodnie z art. 131 u.f.p. obejmowałaby wyłącznie środki na dofinansowanie działalności bieżącej w zakresie określonym w ustawie o oświacie, zaś przeznaczenia takiej dotacji nie należałoby utożsamiać z „celem” wykorzystania dotacji, co z kolei kontrastuje z art. 251 ust 4 u.f.p., który stanowi, że wykorzystanie dotacji następuje przez realizację celów wskazanych w tych przepisach. Jednakże, jak wskazuje A. Ostrowska, dodanie nowych regulacji ustawowych w art. 80 ust. 3d-4 oraz art. 90 ust. 3d-3g i 4 w ustawie o oświacie dały organom stanowiącym jednostek samorządu terytorialnego podstawę do szczegółowego regulowania w swych uchwałach trybu kontroli i prawidłowości wykorzystania dotacji,

8 Ustawa z dnia 7 września 1991 r. o systemie oświaty (tekst jedn. Dz.U. z 2004 r., Nr 256, poz. 2572 ze zm.). 
a w konsekwencji kontrolowanie przez samorządy celowości wydatkowania środków dotacyjnych. Stąd obecnie dotacje oświatowe można uznać za dotacje o charakterze mieszanym, podmiotowo-celowym ${ }^{9}$.

8.

Zatem pojęcie „wykorzystania dotacji” udzielonej w trybie określonym w u.d.p.p.w. w świetle art. 251 ust 4 u.f.p. należy rozumieć nie jako zrealizowanie celu, na który dotacja została udzielona, lecz jako zapłatę za zrealizowanie zadania.

Nie można się zgodzić z argumentacją skarżącego, iż zrealizowanie zadania jest tożsame z wykorzystaniem dotacji. Jak słusznie wskazał sąd, gdyby pojęcia „wykorzystanie dotacji” i „zrealizowanie zadania” były pojęciami tożsamymi, to zbędne byłoby wymienianie w art. 251 ust. 4 u.f.p. zapłaty jako jednego ze sposobów wykorzystania dotacji.

Oceniając wykorzystanie dotacji udzielonej w trybie u.d.p.p.w., należy kierować się kryterium zapłaty za realizację zadania w terminie określonym w umowie. Kwota dotacji niewydatkowana do końca terminu realizacji zadania podlega zwrotowi na rzecz zleceniodawcy. Ewentualne wydatki poniesione po upływie terminu realizacji zadania są wydatkami niekwalifikowanymi i również podlegają zwrotowi.

\section{Bibliografia:}

Musiałkiewicz R., Problemy prawne udzielania dotacji na cele publiczne organizacjom pozarzqdowym przez jednostki samorzqdy terytorialnego [w:] A. Borodo (red.), Zagadnienia prawne finansów i gospodarki samorzq̨u terytorialnego, TNOiK, Toruń 2008.

Ostrowska A., Udzielanie dotacji samorzq̨dowym jednostkom oświaty - samorzqdowa powinność cz samorzqdowe władztwo finansowe [w:] A. Borodo (red.), Dotacje i subwencje w systemie finansowym samorzqdu terytorialnego, TNOiK, Toruń 2013.

9 A. Ostrowska, Udzielanie dotacji samorzqdowym jednostkom oświaty - samorzqdowa powinność czy samorzqdowe władztwo finansowe [w:] A. Borodo (red.), Dotacje i subwencje w systemie finansowym samorzq̨du terytorialnego, Toruń 2013, s. 190. 